\title{
Italique
}

Poésie italienne de la Renaissance

XIV | 2011

Varia

\section{Mouzinho's Sonnet 40: a Reading in four Stanzas}

\author{
Hélio J. S. Alves
}

\section{OpenEdition}

\section{Journals}

Electronic version

URL: http://journals.openedition.org/italique/323

DOI: $10.4000 /$ italique.323

ISSN: 1663-4438

\section{Publisher}

Librairie Droz

\section{Printed version}

Date of publication: 1 January 2011

Number of pages: $47-55$

ISBN: 978-2-600-01536-3

ISSN: 1423-3983

\section{Electronic reference}

Hélio J. S. Alves, « Mouzinho's Sonnet 40: a Reading in four Stanzas», Italique [Online], XIV | 2011, Online since 24 June 2014, connection on 20 April 2019. URL : http://journals.openedition.org/ italique/323 ; DOI : 10.4000/italique.323 
Helio J.S. Alves

MOUZINHO'S SONNET 40 :

A READING IN FOUR STANZAS 



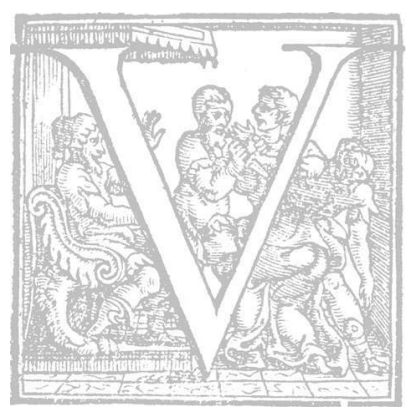

asco Mouzinho, an exact contemporary of Shakespeare's, put into print, in his first volume of poetry of 1596 (Discurso sobre a vida e morte de Santa Isabel Rainha de Portugal, \& outras varias Rimas), a set of $5 I$ sonnets. Some of these poems have been remarked for the depth of their subjectivity, others for their allegorical conventionality. My reading of the sonnet $\mathrm{Nu}$ seco ramo, nu de fruyto e folha (number 40 in the series) will show, however, that Mouzinho was interested, like Petrarch before him, in articulating those two types of discourse together. A poem about love, sonnet 40 is also an intensely meaningful discussion about the connections between intimate 'feeling' (sentir) and outward 'knowing' (conhecer), between old emblematic representation and modern writing on the subject, and therefore about the powers and the limits of poetry itself.

Nũ seco ramo, nu de fruyto e folha, Ũa queixosa rola geme e sente

Do casto ninho seu parceiro ausente, E vê-lo a cada sombra se lhe antolha.

Dali dece a ũa fonte onde recolha Algũ alento, e porque não consente A dor ver água clara, juntamente A envolve c'os pés e o bico molha.

Se ausência e amor sentida a rola tem, Que nem de ausência, nem de amor conhece, Em quem pesar nem sentimento cabe,

Que farão em quem sente o que padece, Quem de seu mal conhece e de seu bem, Temo que venha a não sentir e acabe.

\section{Prima stanza}

Nũ seco ramo, nu de fruyto e folha was written by Vasco Mouzinho, a Portuguese poet who lived sometime between the last third of 
the sixteenth century and the first quarter of the seventeenth. The sonnet is included as number 40 in the author's first printed book, Discurso sobre a vida e morte de Santa Isabel Rainha de Portugal, \& outras varias Rimas, published in I596 (some copies seem to have been printed the year after). The very title Varias Rimas places Mouzinho's lyric output within the framework of Petrarchism, a tendency which was finding a considerable outlet in Portugal during the I590s. The love poetry of Camões (in I595 and I598), of Diogo Bernardes (in I594 and I597) and of the poet hiding under the pseudonym Lizardo (also in 1597), all included the word Rimas in their title-pages and, mostly, also the word Varias. In Mouzinho's case, the reader can tell from the heading of every sheet of paper in the edition that the title Varias Rimas was applied only to the sI sonnets in the book, plus the one poem in terza rima and the only eclogue. Poetry in traditional forms other than of Italian or Classical origin is given different headings. The expression Varias Rimas, therefore, is intended to designate only the lyric forms attached to the prestige of their Italianate sources, a prestige originating from Petrarch's title Rime Sparse, of which Varias Rimas is a translation.

The particular sonnet which concerns me here is grounded in a tradition apparently born with Petrarch's sonnet 353, Vago augeletto che cantando vai. The subject, the lyric ' $T$ ', compares his feelings with those of a little bird singing sadly on a tree branch. The theme was recreated in sixteenth-century Italy in sonnets by Bembo, Solingo augello, se piangendo vai, Francesco Maria Molza, Canoro augello i cui graditi accenti, Chiara Matraini, Vago augelletto mio, caro e gentile, amongst others, and in contemporary Spain in poets like Gutierre de Cetina, Triste avecilla que te vas quejando. In all these examples, essentially from the first half to the middle of the sixteenth century, the imitation of the Petrarchan manner follows a quite evident standard of faithfulness to the Master, despite the new developments, the modifications and the personal traits introduced by each poet. The case we are faced with in Nũ seco ramo, nu de fruyto e folha is quite different from the sonnets previously mentioned, in the sense that, as we shall see, it exposes in word and mood its comparative lateness within Petrarchism.

The bird in this sonnet is not a simple uccello, augello or augelletto but a tortora; in Portuguese, rola, in English, turtle-dove. This could 
indicate specific knowledge of commentaries on Petrarch's 353 or concentrated attention on Bembo's Solingo augello, which describes the little bird as not simply singing with melancholy but also shedding tears for the loss of its consort: piangendo vai / la tua perduta dolce compagnia. Commentaries and hermeneutics may have contributed towards a duplication of the tradition whereby the bird is either a nightingale (usignolo, implied in Petrarch) or a turtle-dove (tortora or tortorino, implied in Bembo). The nightingale, famous for its melodic song, is a melancholic loner; the turtle-dove, on the other hand, is celebrated for living always with the same mate. If this ramification of sources is confirmed, then Mouzinho chose the branch coming from Bembo and introduced a turtle-dove sadly singing the absence of its sexual partner. As opposed to the tradition in Bembo and in the other Petrarchist poets mentioned above, notoriously self-indulgent in the expression of personal emotion, there are hardly any comparisons in our text between the bird and the first person singular. The last line of the poem is the only one which points to the human subject. Why should this be?

\section{Seconda stanza}

Vasco Mouzinho was probably the first Portuguese not only to write verse for emblems but also to include emblems in other poetic genres. As if encouraged by a type of formal exercise, some of Mouzinho's verse written for emblems found its way into his sonnets. ${ }^{{ }}$We know that the turtle-dove appeared in specific emblematic contexts throughout European literature. In such cases, the turtle-dove always meant the same thing: marital fidelity or, at least, monogamy. Ornithology provided the appropriate knowledge turned into symbol. According to Aristotle, the turtle-dove is faithful to a single partner. ${ }^{2}$ It is not surprising, then, that Judeo-Christian culture easily associated the turtle-dove with chastity: the Old Testament includes references to this. ${ }^{3}$ If the biblical metaphor became generally accepted convention, then the barrenness of the branch symbolized sterility after the couple's separation. This is what an informed and cultivated poet like Ariosto meant when he wrote: «come tortora in ramo senza foglie / che poi ch'è priva del fido consorte / sempre più cerca inasperar le doglie». ${ }^{4}$ Here is then the starting-point 
for Mouzinho's sonnet: lines one, two and three refer to a turtle-dove regretting the partner's absence in a nest qualified as chaste, set on a branch without leaves or fruit.'

But the poem introduces other actions too. The little turtle-dove flies down to drink some water from a nearby fountain or water source (lines $5-6)$. The symbol of water as reflection of love or pain, common in courtly poetry, is here joined together with a detail perhaps suggested by the stilnovo and the Petrarchist traditions, i. e., the ghostly figuring forth of the loved one, initially articulated in line $4-$ where the word sombra already insinuates the flashing of spectres - and still implied in line 7. What is literally said in the second quatrain is that, 'because pain does not allow [the turtle-dove] to see clear water', the bird mixes the water with its claws and wets its beak.

The spectral presence of the absent lover passes by, but we are left uncertain about the full meaning of the words. What does 'the bird cannot see clear water' mean? Does it mean that the turtle-dove cannot bear to contemplate transparent waters? Do the bird's eyes, filled with tears, not permit unimpeded views? Or does the turtle-dove see something in the water, perhaps an image of itself, or of its partner, which it tries to catch with its beak and claws? Several answers arise as possible, but the textual evidence is, I think, inconclusive. ${ }^{6}$ Line eight represents the last we hear of the turtle-dove's actions and we cannot really know whether its initial expectations for alento were fulfilled. Perhaps looking at the next few lines will clarify this.

A surprise, though, awaits the reader. As we go from the quatrains to the tercets, the poem changes radically from the emblematic mode to a rationalizing one. Rather than using the symbol of the turtle-dove as a Petrarchist simile of the subject's emotional situation or as an allegory of the subject's feelings - as is to be expected from the use of the emblem or from Petrarch's own use of allegory in the Rime Sparse -, Mouzinho emphasizes that the bird knows nothing of absence, love, sadness or sentiment, it knows nothing about feelings (lines $I 0$ and II). We have been led far away from Petrarch 353 which reads: se, come i tuoi gravosi affanni sai,/ così sapessi il mio simile stato (lines 5-6). By imitating Petrarch (the initial se and the structure of line 9 suggest this), Mourinho is in fact saying, at this stage, that the identification between the turtle-dove and the subject is absurd. 
How can this emphatic difference between the parent poem and its descendant be understood? I would say that the point the Portuguese poet is making is about figurality. The turtle-dove feels absence and love because the emblematic figure declares it does so. In truth, the turtle-dove of this poem is a mere figure of speech. So the meaning of the sonnet and of its intertextuality has shifted from an expression of subjectivity to an expression of poetic figurality. The poem asks not what the feelings of the subject are and how they can be compared to a bird's; it asks rather what means are available to speak about these things.

\section{Terza stanza}

The entire argument of the sonnet runs around the verbs sentir (to feel) and conhecer (to know). The number of times these verbs appear in the text is bighly significant: conhecer turns up twice, in lines ten and thirteen; sentir and its cognates, on the other hand, appear in lines two, six, nine, eleven, twelve and fourteen - no less than six times in all. But sentir can mean not just to feel, but also to sense; that is, it can express a step towards getting to know. Sentir and conhecer, initially opposites - as opposites as the emblem and the living subject - grow to being, at the most, different only in degree.

Lines twelve and thirteen show this quite clearly. The statement 'to feel what one suffers' is made equivalent to, and a synonym of, 'to know your own evil and your good'. The being who feels the pain is the being who knows the self. External form reinforces the idea, as we witness the only internal rbyme of the poem, the rima al mezzo between padece and conhece. At the same time, though, this signifies a difference in essence between the turtle-dove and the human subject: s/be not only feels but also knows. Again, this is a reworking of Petrarch's: se, come i tuoi gravosi affanni sai, / così sapessi il mio simile stato.

Surprisingly, however, the last line of the sonnet gives this idea a twist. By stating 'I fear that s/ he [who feels and knows] may stop feeling and die', the poet literally raises the possibility that the human capacity to know and feel may block feeling and lead to the end (acabe) of the subject. This takes the reader back to something he expected to have already abandoned: the thought that the turtle-dove and the human 
subject are somehow similar. Like the poetic 'I', we as readers now seem ready to accept that the end of the subject may be equivalent to the bird's. After all, the story of the turtle-dove may just be a metaphor for the story of the subject. Similarly, the inanimate figurality of the emblem is ultimately meaningful for the discourse of the subject: both may represent the end. The sense of non-feeling (não sentir), a form of death, perhaps the one real form of death, ends up being shared both by the poem's figure and by its subject. ${ }^{7}$

\section{Quarta stanza}

Our sonnet shows that the meanderings of subjectivity and the allegorical discourse of emblematics converge collaboratively as a single poetic statement. ${ }^{8}$ The author plays on the reader's expectations for a similarity between the bird and the subject, a similarity supported by Petrarchism, and then destroys it by showing the illogicality of the comparison. In the end, though, the poet reconstructs the relationship in new terms. As the Poundian motto goes, Mouzinho literally (re)makes it new. Readers should note that this is done without sacrifice, either of the values of allegory, or of the sophisticated discourse of subjectivity. The poem includes daring metaliterary reflections on the powers and limits of meaning as produced by different methods of writing. In this sense, the last line represents extremes of intensity, since it reaches the point of inexpressibility. As the subject's emotions exceed the figural capacity to carry them, they also signal the fear that, like the mute disappearance of the turtle-dove, the poet's speech will forcibly cease to be. Subject and poet coincide in the silence which coincides also with the end of the poem. Não sentir, to feel not, and acabe, finish, become the words which express, not only what the subject fears for himself, but also what is already bappening, ominously, to the sonnet.

Mouzinho closes the poem by signaling a close. Accordingly, all that remains for me to do is to close this reading too.

Helio J. S. Alves 
I. On the lyric poetry and the emblematics of Vasco Mouzinho, see A. J. Saraiva and O. Lopes, História da Literatura Portuguesa, I Gth edition, Porto: Porto Editora, 1992, pp. 367-8; Teresa M. R. Calado Tavares, Os emblemas de Vasco Mousinho Quevedo de Castelbranco, Masters dissertation, Lisbon: Faculdade de Letras, I988; Maria Vitalina L. de Matos, «Vasco Mousinho Quevedo Castelbranco», Arquivos do Centro Cultural Português, vol. 37, Lisbon-Paris, I998, pp. 417-34; Maria José Gamboa, Discurso sobre a vida e morte da Rainha Santa Isabel e outras varias Rimas de Vasco Mousinho Quevedo de Castelbranco e a poesia ao divino, Masters dissertation, Coimbra: Faculdade de Letras, I 999; Isabel Almeida, «Fina prata': os 'Dialogos de varia doutrina illustrados com emblemmas', de Vasco Mousinho de Quevedo», Românica, vol. 9 (2000), pp. 77-88; Luís Gomes, "Vasco Mousinho de Quevedo Castelo Branco: emblems in Portuguese», in Luis Gomes (ed.), Mosaics of Meaning: Studies in Portuguese Emblematics, Glasgow: Glasgow Emblem Studies, 2008, pp. 4I-64. Chapter six of my book Tempo para Entender. História comparada da literatura portuguesa (Casal de Cambra: Caleidoscópio, 2006) concerns partly Mouzinho's lyricism.

2. Aristotle, Historia Animalium, 9.7; 6 2 2b 33 ff.

3. Isaiah 38.14 and 59.1 I; Erekiel 7.16; Song of Songs 2:14, 5:2 and 6.9.

4. Ariosto, Eclogue I, vv. 229-3i.

5. Notice the extra detail about fruit, absent from the main tradition. The most widely acceptable interpretation for this would be that the turtle-dove has no offspring and, in a sense, no future.

6. Open interpretations of this stanza could take us far into discussions of the theory of love, mirror images and other cultural issues of considerable bearing for the sonnet. Nevertheless, the obscurity of the phrase in lines six to eight and the crucial issue of interpretive relevance to the text advise this reader not to follow that path as yet.

7. The sonnet thus invites the interpreter to make direct comparisons, especially between the more original part of Mouzinho's reference to the bird, namely the dive into the fountain or source (fonte) to find alento, and the subject's situation as described in the tercets. It is not a coincidence that the two Portuguese words have technical meanings commonly assigned to them in Renaissance rhetoric and poetics. Poets required alento and frequently asked the gods and muses for it in invocations; fonte represents the other side of the Classical act of producing discourse, the requirement of a model to imitate. The conversion of the turtledove into figure, once the simile is confirmed, turns the subject into a figure too and the sonnet as a whole into a reflection about this poet's existence as poet.

8. Critics have tended to produce the image of a schizoid Vasco Mouzinho, valuable in the subjective manner he utilizes in some poems, almost worthless in the allegorical mode employed in others. I believe this to be a false dichotomy and hope this article may contribute to a change of mind about this splendid poet. 